\title{
Three-step checklist for tracheostomy in critically ill COVID-19 patients
}

\author{
Maria Vargas ${ }^{*}$ (i) and Giuseppe Servillo
}

Tracheostomy is a common procedure in critically ill patients requiring prolonged mechanical ventilation [1]. The use of tracheostomy can facilitate weaning from ventilation and potentially increase the availability of intensive care unit (ICU) beds [2]. When the COVID-19 pandemic spread all around the world, ICUs had a massive influx of critically ill patients, many of whom became candidates for tracheostomy [2]. Tracheostomy is an aerosol-generating procedure that exposes physicians at high risk to contract infections [3]. In COVID-19 patients, healthcare workers who do tracheostomies must take into account additional considerations associated with the infectivity of SARS-CoV-2 [4]. Recent reports suggested to perform surgical and percutaneous tracheostomies with modified techniques to minimize the aerosol and then to keep the personnel safe [5, 6]. Although performing tracheostomy in COVID-19 patients is a high-acuity setting [6]. With such broad recognition of the importance of safety, we propose a three-step checklist to optimize the process of performing tracheostomy in critically ill COVID-19 patients (Fig. 1). The three- step checklist for tracheostomy in COVID-19 patients involves a preparation phase, a procedural phase, and an evaluation phase at the end of the procedure (Fig. 1). The preparation phase is intended to optimize all the action to prepare the patient and the staff for the procedure. The procedural phase includes the operative steps to perform the procedure with additional safety while the evaluation phase is intended to check the patient at the end of tracheostomy. Key points of this three-step checklist are proper wearing of personal protective equipment and actions to reduce the risk of viral aerosolization like pushed down the endotracheal tube and keep it cuffed during the procedure. We used the three-step checklist for tracheostomy in 3 percutaneous technique and 2 surgical techniques performed in critically ill COVID-19 patients, and we found that it is beneficial in preventing errors and harms. The threestep checklist for tracheostomy in critically ill COVID-19 patients is tailor-made to improve the safety and efficiency of a high-risk procedure for healthcare works.

\footnotetext{
* Correspondence: vargas.maria82@gmail.com

Department of Neurosciences, Reproductive and Odontostomatological

Sciences, University of Naples "Federico II", via Pansini, Naples, Italy
}

(c) The Author(s). 2020 Open Access This article is licensed under a Creative Commons Attribution 4.0 International License, which permits use, sharing, adaptation, distribution and reproduction in any medium or format, as long as you give appropriate credit to the original author(s) and the source, provide a link to the Creative Commons licence, and indicate if changes were made. The images or other third party material in this article are included in the article's Creative Commons licence, unless indicated otherwise in a credit line to the material. If material is not included in the article's Creative Commons licence and your intended use is not permitted by statutory regulation or exceeds the permitted use, you will need to obtain permission directly from the copyright holder. To view a copy of this licence, visit http://creativecommons.org/licenses/by/4.0/ The Creative Commons Public Domain Dedication waiver (http://creativecommons.org/publicdomain/zero/1.0/) applies to the data made available in this article, unless otherwise stated in a credit line to the data. 


\section{THREE-STEP CHECKLIST FOR TRACHEOSTOMY IN COVID-19 PATIENT}

\begin{tabular}{|c|c|c|}
\hline \multicolumn{3}{|c|}{ PREPARATION } \\
\hline $\begin{array}{l}\text { Confirm patient's consent or next of } \\
\text { kin's assent }\end{array}$ & Yes & No \\
\hline $\begin{array}{l}\text { Perform neck ultrasound to evaluate } \\
\text { the presence of at-rick structure }\end{array}$ & \multicolumn{2}{|c|}{ Report: } \\
\hline Check coagulation & \multicolumn{2}{|c|}{$\begin{array}{l}\text { Platelet count: } \\
\text { INR } \\
\text { APTT }\end{array}$} \\
\hline $\begin{array}{l}\text { Anticoagulant and antiplatelet } \\
\text { withheld? }\end{array}$ & \multicolumn{2}{|c|}{$\begin{array}{l}\text { Which? } \\
\text { Withheld when? }\end{array}$} \\
\hline Gastric feeding suspended? & Yes & No \\
\hline \multicolumn{3}{|l|}{ Airway rescue equipment? } \\
\hline Videolaryngoscope & & \\
\hline Endotracheal tubes & Yes & No \\
\hline Supraglottic airway devices & & No \\
\hline Introducer/bougie & Yes & No \\
\hline Airway exchange catheters & & No \\
\hline Bag Valve Mask Ventilation & & No \\
\hline Scalpel & Yes & No \\
\hline - Complete cricothyrotomy kit & Yes & No \\
\hline Wear third level PPE: & Yes & No \\
\hline - Helmet in place of FFP3 & Yes & No \\
\hline - Facial shield & & \\
\hline Long sleeve fluid-resistant & Yes & No \\
\hline scrubs & Yes & No \\
\hline $\begin{array}{ll}\text { - Double gloves } \\
\text { - Overshoes }\end{array}$ & Yes & No \\
\hline
\end{tabular}

\begin{tabular}{|c|c|c|}
\hline & & ROCE \\
\hline Full Monitoring of vital parameters? & Yes & No \\
\hline $\begin{array}{l}\text { Report vital parameters at the beginning of the } \\
\text { procedure }\end{array}$ & & \\
\hline Doctor in charge for the airway management is? & $\mathrm{Dr}$ & \\
\hline Doctor performing tracheostomy is? & $\mathrm{Dr}$ & \\
\hline Perform general and local anesthesia & $\begin{array}{l}\text { Which } \\
\text { drugs? } \\
\text { Which } \\
\text { dose? }\end{array}$ & \\
\hline $\begin{array}{l}\text { Optimize mechanical ventilation (report the } \\
\text { parameters): } \\
-\quad \text { Volume control ventilation } \\
-\quad \text { Respiratory rate } \\
-\quad \text { FiO2 } \\
\text { - Tidal volume } \\
\text { - }\end{array}$ & & \\
\hline $\begin{array}{l}\text { Perform } 5 \text { minutes of preoxygenation with FiO2 } \\
100 \%\end{array}$ & Yes & No \\
\hline $\begin{array}{l}\text { Change the endotracheal tube in place with a } \\
\text { smaller tube with an internal diameter of } 5 \text { or } 6 \mathrm{~mm}\end{array}$ & & No \\
\hline $\begin{array}{l}\text { Cuff the endotracheal tube at the level of the carina } \\
\text { and connect the mechanical ventilator } \\
\text { (check it with the airway pressure and the end-tidal } \\
\text { CO2) }\end{array}$ & Yes & No \\
\hline
\end{tabular}

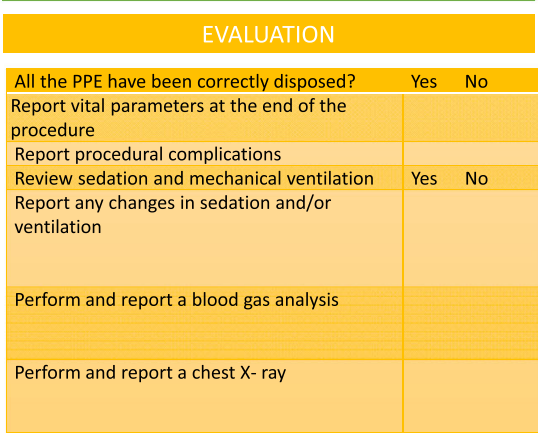

\section{DEURE}

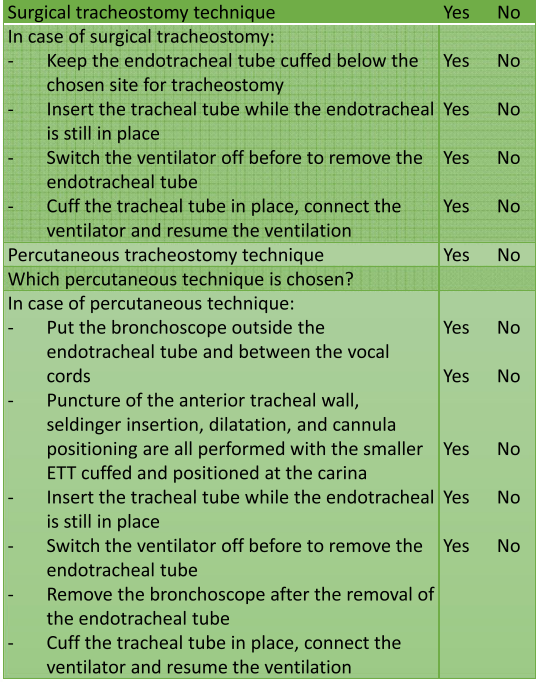

Fig. 1 Three-step checklist for tracheostomy in critically ill COVID-19 patients

\section{Acknowledgements}

NA

\section{Authors' contributions}

MV and GS planned the manuscript, collected the data, wrote the manuscript, and approved the final version.

\section{Funding}

None

\section{Availability of data and materials}

NA

\section{Ethics approval and consent to participate}

NA

\section{Consent for publication \\ Yes}

\section{Competing interests}

None

Received: 20 May 2020 Accepted: 27 May 2020

Published online: 08 June 2020

\section{References}

1. Vargas M, Sutherasan Y, Antonelli M, et al. Tracheostomy procedures in the intensive care unit: an international survey. Crit Care. 2015;19:291-301.
2. McGrath BA, Brenner MJ, Warrillow SJ. et al. Tracheostomy in the COVID-19 era: global and multidisciplinary guidance. [Published online May 15, 2020] Lancet Respir Med 2020, doi: https://doi.org/10.1016/S2213-2600(20)30230-7.

3. Givi B, Schiff BA, Chinn SB, et al. Safety recommendations for evaluation and surgery of the head and neck during the COVID-19 pandemic. [published online March 31, 2020]. JAMA Otolaryngol Head Neck Surg. https://doi.org/ 10.1001/jamaoto.2020.0780.

4. Vargas M, Servillo G. Improving staff safety during tracheostomy in COVID19 patients. Head Neck. 2020. https://doi.org/10.1002/hed.26163 [Epub ahead of print].

5. Vargas M, Russo G, lacovazzo C, Servillo G. Modified percutaneous tracheostomy in COVID-19 critically ill patients. Head Neck. 2020:1-4. https://doi.org/10.1002/hed.26276.

6. Portugal LG, Adams DR, Baroody FM, Agrawal N. A surgical safety checklist for performing tracheotomy in patients with coronavirus disease 19 [published online ahead of print, 2020 Apr 28]. Otolaryngol Head Neck Surg 2020;194599820922981. doi:https://doi.org/10.1177/0194599820922981.

\section{Publisher's Note}

Springer Nature remains neutral with regard to jurisdictional claims in published maps and institutional affiliations. 